Human Journals

Review Article

November 2019 Vol.:14, Issue: 1

(C) All rights are reserved by José Carlos da Silva Freitas Junior et al.

\title{
Design Science Research in Developing Leadership in Virtual Worlds
}

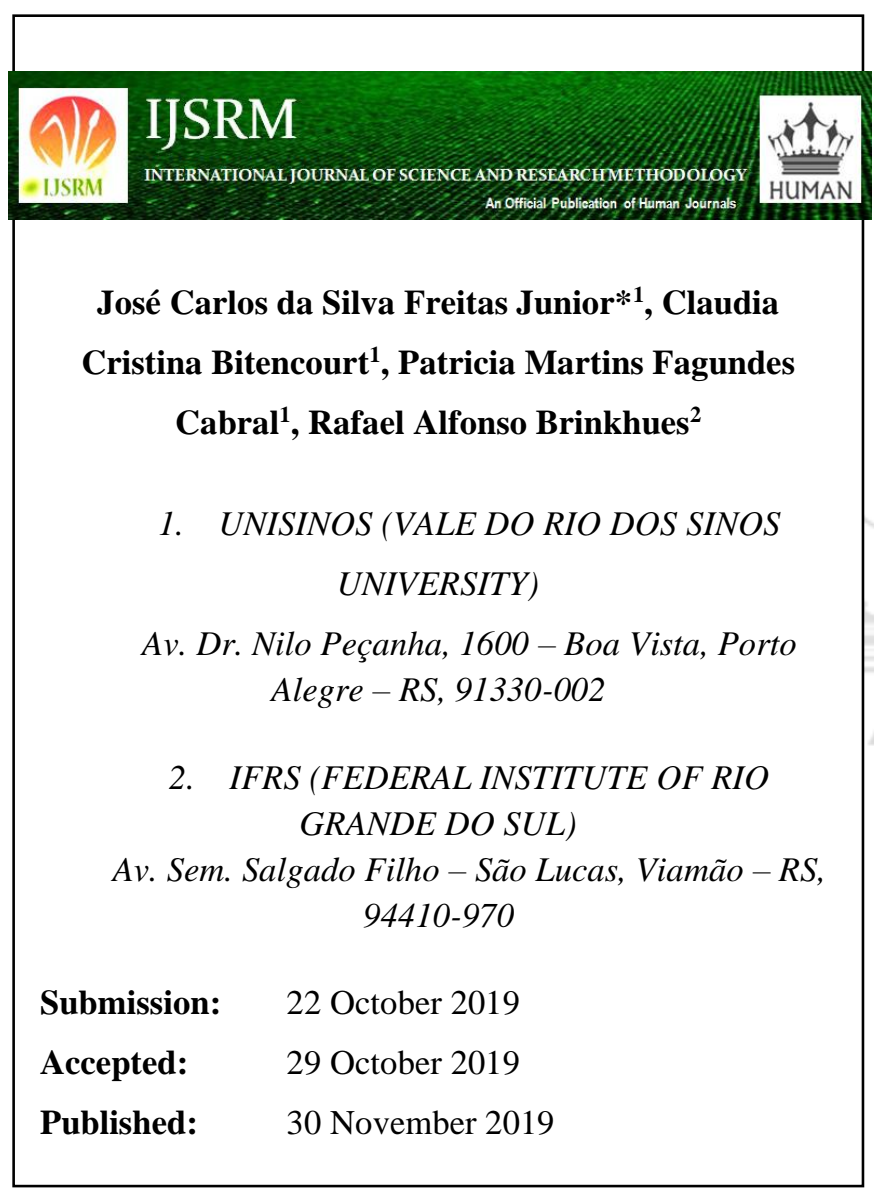
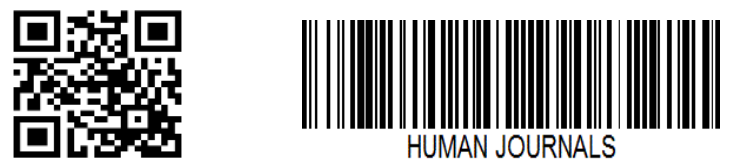

www.ijsrm.humanjournals.com
Keywords: Design Science Research, Leadership, Metaverse, Competence

\section{ABSTRACT}

This paper discusses the Design Science Research (DSR) approach applied in the development of leadership skills in undergraduate business administration students. The development of leadership skills is essential for managers; however, business undergraduate courses do not provide many opportunities and spaces for students to develop their skills. To fill this gap, using the DSR method it was possible to build, test and evaluate an artefact that could be utilized as a training method for leadership development in the threedimensional virtual world Second Life. The research was developed in a business administration undergraduate course in one university in South Brazil. This paper describes the steps of the research showing all methodological considerations and accordingly its contribution to rigor and relevance in the DSR domain. The results demonstrate that DSR is an appropriate approach to study and develop competencies in practice. Furthermore, it was possible to identify the possibilities and limitations of the artefact. The results also indicate that this virtual environment has the resources for the user to encounter a context close to reality. Finally, this paper is useful to researchers who wish to apply the DSR method and serves as supporting material for teaching management, as the created artefact can be totally or partially replicated. 


\section{INTRODUCTION}

In recent years, important methodological contributions on how to conduct Design Science Research (DSR) have emerged (e.g., Baskerville, Baiyere, Gregor, Hevner \& Rossi 2018; Gregor, Müller \& Seidel, 2013; Hevner, March, Park \& Ram, 2004; Kuechler \& Vaishnavi, 2012). There has also been a consensus regarding the outcomes of DSR at different levels of abstraction, completeness and maturity, including instantiations and nascent design knowledge such as design principles (Gregor \& Hevner, 2013). Contrary to a behavioral research paradigm which aims at describing, explaining and predicting the individual, organizational or social effects of the use of technology, DSR is concerned with "the systematic creation of knowledge about, and with (artificial) design" (Baskerville \& PriesHeje, 2010). Researchers can readily choose between several approaches to structure, document and evaluate their research and all involve multiple iterative cycles, including phases of identifying problems, designing, implementing and evaluating solutions, learning from this process and communicating the results (Gregor, Müller \& Seidel, 2013; Mettler, Eurich \& Winter, 2014; Baskerville et al., 2018).

In this context, the purpose of this paper is to discuss a practical application of the DSR method in the training of undergraduate business administration students. According to Baskerville et al. (2018), DSR contributes both practical relevance (via its emphasis on useful artefacts) and scientific rigor (via the formulation of design theories) to research. This study followed the research steps suggested by Hevner, et al. (2004) and Manson (2006) which comprised understanding or awareness of the problem, suggestions, development, evaluation and conclusions.

In short, it was noted that managers' leadership development has been a target since undergraduate degrees in Business Administration. However, curricula tend to turn to theoretical elements and gauging cognitive knowledge. Consequently, these students do not have many opportunities to develop and practice this competence (Cascio \& Boudreau, 2016). In response to this gap, this research presents a methodology to develop leadership competencies in virtual worlds. Virtual space was selected since it offers practical experience in a viable space-time in organizational management courses, as generating these experiences in a real context is not always possible during the regular course of undergraduate subjects. 
To achieve this objective it was necessary to identify a suitable environment to provide the opportunity for students to practice, to be challenged and to lead teams, among other opportunities to obtain practical experience. Accordingly, the researchers considered threedimensional virtual worlds, also known as metaverses (Vrellis, Avouris, \& Mikropoulos, 2016), as an alternative that could facilitate this aim, because it has features that can allow users to experience lifelike situations, allowing them to develop their competencies in action (Zarifian, 2001; Le Boterf, 2006).

Consequently, this paper describes the development and application of an artefact in the form of a training method for the development of leadership skills. However, the usefulness and applications of this method have wider relevance. The training method proposed in this research can also be used in corporate universities and in the training strategies of organizational leaders. Focusing on the use of DSR, this study explains how knowledgeguided artefact design and the type of scholarly knowledge that results from artefact design have emerged.

In this sense, the research question of this study was: "How could metaverses be used as an environment for the development of leadership skills in business administration higher education?" The researchers followed a number of propositions that were possible answers to this question, such as that the use of metaverses positively contributes to the development of leadership competency by enabling the simulation of real work situations and allows consideration of experiences that would not be possible in other contexts, such as face-to-face or virtually, and enables a virtual environment with rich resources for interaction between leaders and their followers.

The research was developed in the business administration undergraduate course "Management for Innovation and Leadership" in a university located in South Brazil. This study used the DSR approach with the aim of designing an educational method for leadership development inside the metaverse Second Life (SL).

Consequently, it is important to highlight that this paper describes research focusing on a contribution to rigor and relevance in DSR. The results demonstrate that DSR is an appropriate approach to study and develop competencies in practice. Moreover, this study provides guidance for researchers who wish to apply this method, describing in detail the steps for conducting research on management. In addition, this research shows how to 
optimize time and space with the use of virtual technologies, as well as highlighting that the domain of digital technologies integrates key competencies for the leaders of today.

This paper is structured as follows: the next section discusses the DSR method followed by an application of DSR in one research study. Subsequently, evidence is provided of the contributions of this research, highlighting the knowledge generated and the importance and rigor of the method followed by a discussion of the final considerations.

\section{Design Science Research}

The DSR research method involves analyzing the use and performance of artefacts designed to understand, explain and improve the behavior of certain aspects in information systems (Vaishnavi \& Kuechler, 2004).

This methodology incorporates the principles, practices and procedures necessary for conducting research and fulfilling three requirements: a) consistency with the previous literature; b) the provision of a procedural model for replicating the approach; and c) the provision of a mental model for the presentation and evaluation of design research (Peffers, Tuunanen, Rothenberger \& Chatterjee, 2007).

The fundamental principle of DSR is that knowledge and understanding of a problem and its solution are acquired in the construction and application of an artefact to a specific problem context (Mettler, Eurich \& Winter, 2014).

Furthermore, DSR is responsible for designing and validating systems that do not yet exist, whether creating, recombining or changing products/processes/software/methods to improve existing situations (Lacerda, Dresch, Proença \& Antunes Júnior, 2013).

As a starting point, it is necessary to understand that design is knowledge in the form of techniques and methods for mapping of the need for the creation of an artefact that satisfies a set of functional requirements (Vaishnavi \& Kuechler, 2004). That is, it is a system of principles, practices and procedures applied to a specific branch of knowledge (Peffers et al., 2007), translated into artefacts that are usually designed to satisfy a need or to achieve some purpose and which are the interface between the external environment and the situation in which they should function, including all natural laws governing its operation, the internal environment, the substance and the organization of the artefact itself (Simon, 1996). 
In synthesis, DSR can be defined as "a process of using knowledge to design and create useful artefacts and then using various rigorous methods to analyze why, or why not, a particular artefact is effective. The understanding gained during the analysis phase feeds back into and builds the body of knowledge of the discipline." (Manson, 2006, p. 161). It is worth mentioning that the artefact itself is not necessarily the main result of DSR. The results of the application of Design Research are diverse, as described in Table 1.

Table No. 1: The outputs of design science research

\begin{tabular}{|l|l|}
\hline Output & Description \\
\hline Constructs & $\begin{array}{l}\text { The conceptual vocabulary of a domain and are a concept used to describe } \\
\text { the problems within the domain and to specify their solutions. }\end{array}$ \\
\hline Model & $\begin{array}{l}\text { A set of propositions or statements expressing relationships between } \\
\text { constructs. In design, the models represent situations such as problems and } \\
\text { solutions statements. } \\
\text { A model can be seen simply as a description, that is, as a representation of } \\
\text { how things are. }\end{array}$ \\
\hline Methods & $\begin{array}{l}\text { A set of steps used to perform a task how-to knowledge. The methods can } \\
\text { be linked to models, where the steps of the method can use parts of the } \\
\text { model as an input that composes it. }\end{array}$ \\
\hline Instantiations & $\begin{array}{l}\text { The operationalization of constructs, models, and methods. However, an } \\
\text { instantiation may, in practice, precede the complete articulation of its } \\
\text { constructs, models, and methods. They demonstrate the feasibility and } \\
\text { effectiveness of the models and methods they contemplate. }\end{array}$ \\
\hline innovations & $\begin{array}{l}\text { Solutions are driven by the goals of enhancing human experiences, } \\
\text { maximizing economic utilities, and building sustainable environments (e.g. } \\
\text { Mobile Applications) }\end{array}$ \\
\hline The construction of an artefact analogous to experimental natural science
\end{tabular}

Note. Source: Adapted from Manson (2006), Vaishnavie Kuechler (2004); Freitas Junior, Machado, Klein, \& Freitas (2015) and Baskerville et al. , 2018.

Furthermore, the development and application of the DSR methodology establish a sequence of steps to achieve the defined objectives. This study followed the five steps proposed by Manson (2006, pp162-163): 


\section{Awareness of the Problem}

The research process begins when the researcher becomes aware of a problem. This awareness may be brought to the researcher's attention from industry or government, from new developments in technology, from reading in related disciplines, or from many other sources. The researcher will then construct a formal or informal proposal to begin a new research effort, which is the output of this stage of the process.

\section{SUGGESTION}

During the Suggestion phase, the researcher will come up with one or more Tentative Designs. These tentative designs are intimately connected to the proposal, and any formal proposal for funding will usually include at least one tentative design. If the researcher cannot formulate a tentative design, the research effort will usually be set aside. This step is essentially creative, and it is in this phase that different researchers will arrive at different tentative designs. This step is analogous to the process of theorizing in Natural Science, where different researchers may arrive at different theories to explain the same set of observations.

\section{DEVELOPMENT}

During this phase, the researcher will build one or more Artefacts. The techniques used will vary widely, depending on the artefacts being constructed. Some examples of artefacts are algorithms with a formal proof, software, and expert systems. The construction itself may not require any novelty beyond the state-of-practice, as the novelty is primarily in the design.

\section{EVALUATION}

Once constructed, the artefact must be evaluated against the criteria that are either implicitly or explicitly contained in the proposal. Any deviations from the expectations must be tentatively explained. Before, and during construction, researchers will make hypotheses about how the artefact will behave. Rarely, in Design Research, are these initial hypotheses completely validated. In strict positivist research, this phase allows the researcher to determine whether the hypothesis has been falsified or not, and this marks the conclusion of the research effort. New knowledge is produced as indicated by the Circumscription and Operation and Goal Knowledge arrows. Circumscription is a formal logical method that 
assumes that every fragment of knowledge is valid only in certain situations. Further, the applicability of knowledge can only be determined through the detection and analysis of contradictions when things do not work, and the researcher is forced to go back to the Awareness stage, new Constraint Knowledge is gained that refines the boundaries of the always-incomplete theory that was used to design the artefact in the first place. If the researcher is able to solve the problem, this may also lead to new understanding that will modify and improve the original theory.

\section{CONCLUSION}

At some point, even though there may still be deviations in the artefact's behavior from the, possibly multiply, revised hypotheses, the effort is considered good enough. The results are then consolidated and written up. Knowledge produced is classified as firm or as loose-ends. Firm knowledge are facts that have been learnt and can be applied repeatedly. Loose-ends are anomalies that cannot be explained, and frequently become the subject of further research.

To illustrate the application of DSR in practice, the following section presents research developed following the rigor of the DSR method in all phases.

\section{The Development of the DSR Method Applied to Research}

This section reports a practical application of DSR as a research methodology with the aim of creating an artefact to enable the development of leadership skills in a virtual environment, the three-dimensional virtual world SL. To accomplish this result, the construction of this artefact followed all design research steps suggested by Manson (2006), as illustrated in Figure 1. 


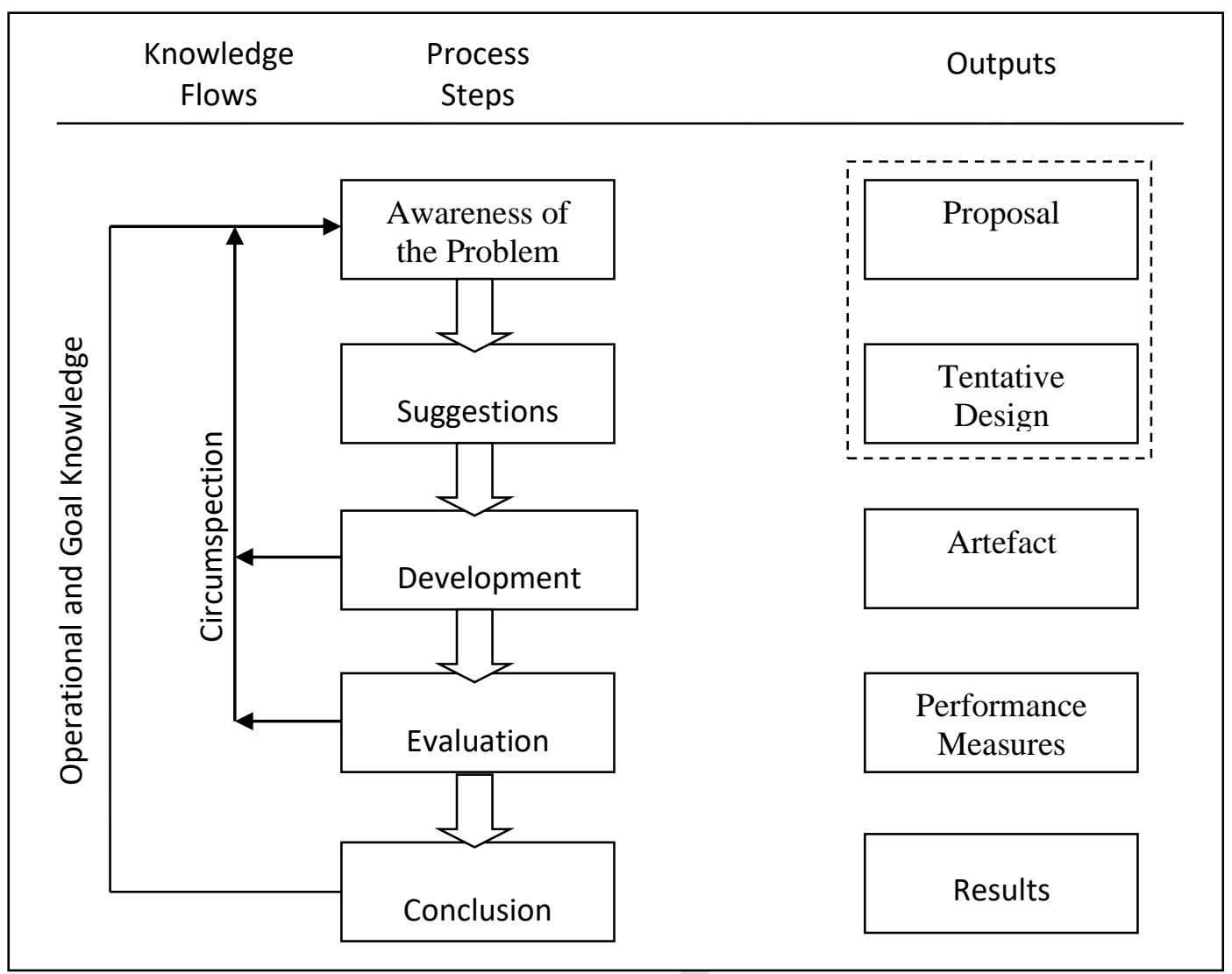

Figure No. 1: - The general methodology of design research

Note: Source: Adapted from Vaishnavi \& Kuechler (2004) and Manson (2006)

Based on these steps, this paper presents the development of the research from its conception and the first awareness of the problem to the conclusion of the study.

\subsection{Awareness of the Problem}

DSR researchers by and large agree that every DSR project starts with identifying an important problem in a business or other setting (e.g., Gregor \& Hevner, 2013; Hevner et al., 2004; Peffers et al., 2007).

In this study, this phase was one of the longest, based on reading, discussions, interviews and meetings with professionals with recognized knowledge in the scope of the university in which the research took place. 
The literature review sought to better understand contemporary leadership skills, which should be worked through in the metaverse SL, with the students participating in this experience. Accordingly, the understanding of leadership has been adopted as the process of providing direction and influencing individuals or groups so that common goals are achieved (Hitt, Miller \& Colella, 2007).

In the study of the profile of the leader, personal and interpersonal capabilities were identified after a systematic literature review. According to Vries (1997), Bennis, Nanus and Simõés (1988), Bennis and Levy (1996), Coda and Bergamini (1997), Rowe, (2002), Rochlin (2005), Hitt, Ireland and Hoskisson (2012), Porter and Kramer (2009) and Botha and Claassens (2010), the leadership capabilities can be synthesized as follows:

a. Relationship (internally and externally)

b. Resilience/adaptation to change

c. Ability to take risks and make decisions

d. Ability to stimulate/mobilize and develop people (so that the leader is motivated)

e. Capability for planning and systemic vision (strategic)

The second theoretical topic of research was the three-dimensional virtual worlds for the development of leadership skills defined on the basis of the literature review. These virtual worlds are also called metaverses. A metaverse is characterized by the convergence between physical reality, virtually amplified and virtual space, and is physically persistent (Smart, Cascio \& Paffendorf, 2007).

Consequently, researchers have used the affordances theory to understand the possibilities of metaverses and the resource properties between an artefact and an actor, that is, the way in which a user interacts with an object, perceives and exercises its possibilities of use (Andreas, Tsiatsos, Terzidou \& Pomportsis, 2010).

Affordances are the characteristics of a technology that determine whether and how particular learning behavior can occur within a given metaverse (Girvan \& Savage, 2010) as well as also being the properties of the virtual world that are compatible and relevant to people's interaction (Gaver, 1991). For the development of this research consideration was given to 
the affordances defined by Bronack (2011), Warburton (2009), Salmon (2009), Lu (2010) and Dalgarno (2010) as follows: simulation, interaction, visualization and contextualization, collaboration, feeling of presence, communication, community presence and content production.

Based on the literature review we sought to understand the context of the research application. It was then possible to define the students who would participate in the experience. Considering the undergraduate courses available, a management course called "Management for Innovation and Leadership" was selected on the basis of: the focus on leadership; the fact that the course is full-time, as it was believed that there would be more flexibility regarding schedules for the development of the research; and the support of the course coordinators, who saw in the research proposal an opportunity for innovation, which is one of the goals of the course.

For data collection, semi-structured interviews and field diaries were used. Interviews with teachers and students were conducted in order to understand the context and the interviewees' understanding of leadership competencies. The field diary systematically recorded all the researcher observations.

This course is structured in Learning Programs (LP) rather than semesters or school years, as is the case in most undergraduate courses. The search context was LP 2. Interviews were conducted with five teachers, on the basis of their coordination of the course due to their subjects of study, and four students from LP 5.

The choice of the students was random, the criterion of completing LP 5 was intentional since these students had already passed the middle of the course and therefore had a broader view of the leadership development process.

Table 2 describes the interviewees. The duration of the interviews ranged from thirty to sixty minutes and all interviews were carried out in person at university. They were recorded with the permission of the interviewees for further analysis. 
Table No. 2: Interviewee Profile

\begin{tabular}{|c|c|c|}
\hline Interviewee & Interviewee & Summarized Professional Profile \\
\hline A & $\begin{array}{l}\text { Coordinator } \\
\text { and lecturer }\end{array}$ & $\begin{array}{l}\text { Ph.D. student with a master's degree in management with } \\
\text { teaching experience for more than six years, teaching at } \\
\text { UNISINOS since } 2009 \text { at undergraduate and postgraduate } \\
\text { level. Acting in the area of people management. }\end{array}$ \\
\hline B & $\begin{array}{l}\text { Coordinator } \\
\text { and lecturer } \\
\text { of the } \\
\text { innovation } \\
\text { axis }\end{array}$ & $\begin{array}{l}\text { Master in business administration, with teaching experience } \\
\text { since 1997, working at UNISINOS since this year in } \\
\text { undergraduate and postgraduate education. Acts on the } \\
\text { subject of Knowledge Management. }\end{array}$ \\
\hline $\mathrm{C}$ & Lecturer & $\begin{array}{l}\text { She has also been a consultant for companies in the areas of } \\
\text { human resources management, team development and family } \\
\text { business. }\end{array}$ \\
\hline $\mathrm{D}$ & $\begin{array}{l}\text { Coordinator } \\
\text { and } \\
\text { professor of } \\
\text { the } \\
\text { leadership } \\
\text { axis }\end{array}$ & $\begin{array}{l}\text { Ph.D. in Psychology and Master in Business Administration. } \\
\text { She has been a professor at UNISINOS since } 1996 \text { with } \\
\text { experience in the areas of work and HR psychology, working } \\
\text { in the areas of leadership development, organizational } \\
\text { behavior and people management. }\end{array}$ \\
\hline $\mathrm{E}$ & Lecturer & $\begin{array}{l}\text { Master in Science and Technology Management and Ph.D. in } \\
\text { Science Policy and Technology. She has been a professor at } \\
\text { UNISINOS since 2000. She has experience in teaching and } \\
\text { academic research at UNICAMP, UFRGS and UNISINOS, } \\
\text { working in the area of people management and leadership }\end{array}$ \\
\hline T.M. & Student & \multirow{4}{*}{$\begin{array}{l}\text { Students aged between } 16 \text { and } 18 \text { years old, completing PA5 } \\
\text { during the interview period. }\end{array}$} \\
\hline M.W & Student & \\
\hline T.T. & Student & \\
\hline C.C. & Student & \\
\hline
\end{tabular}

Note. Source: Research data

In summary, these interviews allowed the researcher to investigate how leadership competence was being developed in the researched context and to verify if the interviewees knew about virtual worlds such as SL. In cases where the interviewee did not know SL, it was briefly considered if this three-dimensional virtual environment, in the interviewees' perception, could be used for the development of leadership competence.

In addition, it was possible to understand the context and identify the leadership attributes targeted by the course. The results were analyzed in light of the literature. At this point, the limit between this step and the next step narrows; the information and the understanding of the problem do not end, so the actions were adjusted during the suggestion phase. 


\subsection{SUGGESTIONS}

This second step determined the design of the artefact. According to Baskerville et al. (2018), artefact construction is not always dependent on any underlying non-design knowledge. Methods for building and evaluating artefacts can develop over time through processes of trial and error, long before there is a deep understanding of relevant non-design knowledge.

In this second step, a few attempts were made to plan the design of each part of the artefact, from the planning of the leadership training activity to the evaluation and creation of the virtual environment on the university island within the metaverse SL.

Initially, several activities were considered until the research team defined which activities would be proposed to the students to be performed in the virtual environment, enabling a vision of the artefact as a whole based on the necessary requirements for the creation of the training activities.

Such requirements can, for instance, be based on the results from expert interviews, literature reviews or observations. Researchers widely distinguish between functional and nonfunctional requirements (Sommerville, 2016). After these definitions, a professional in virtual worlds design/programming was contracted to construct the virtual environment to begin the next step, development.

\subsection{Development}

In this phase, it is important to keep in mind that the goal of DSR is to invent new artefacts where none exist and to improve existing artefacts to enhance organizational, group and individual human productivities and effectiveness (Baskerville et al., 2018). A primary rationale for the DSR paradigm is to establish rigorous ground rules for growing knowledge contributions around building and evaluating the IT artefact (Hevner et al., 2004).

In this step, the artefact (method for leadership development training) was effectively conceived and applied, based on activities that mobilized the attributes of leadership and according to the affordances of the metaverse defined from the literature review.

The entire training process and the evaluation of the development of leadership attributes during this process were considered through an interactionist and constructivist teachinglearning conception. 
In this sense, the evaluation aimed to contribute as a whole to the qualification of the training process, since it provided constant feedback to the student and to the facilitator, the training process itself and the system (Saccol, Schlemmer \& Barbosa, 2011). Based on these conceptions, several activities were performed throughout the training (application of the artefact), as shown in Table 3.

Table No. 3: Leadership Training Steps

\begin{tabular}{|c|c|c|}
\hline Step & Activity & Goal \\
\hline $\begin{array}{l}\text { Application } \\
\text { of self- } \\
\text { assessment } \\
\text { instrument }\end{array}$ & $\begin{array}{l}\text { Initial diagnostic } \\
\text { self-assessment }\end{array}$ & $\begin{array}{l}\text { Students individually responded to a quantitative- } \\
\text { qualitative diagnostic tool for their leadership } \\
\text { competency (by self-assessment). }\end{array}$ \\
\hline $\begin{array}{l}\text { Preparatory } \\
\text { Activity }\end{array}$ & $\begin{array}{l}\text { Second Life } \\
\text { Training }\end{array}$ & $\begin{array}{l}\text { Face-to-face training on the initial knowledge needed } \\
\text { to use SL. }\end{array}$ \\
\hline 1 st meeting & $\begin{array}{l}\text { Virtual Interaction: } \\
\text { Exploring the 3D } \\
\text { World. }\end{array}$ & $\begin{array}{l}\text { Meeting in SL, for ambiance. It also included } \\
\text { theoretical discussions on leadership and integration } \\
\text { dynamics, mediated by the principal investigator } \\
\text { acting as a facilitator. }\end{array}$ \\
\hline 2nd Meeting & $\begin{array}{l}\text { Activity: Global } \\
\text { leader x Local } \\
\text { leader }\end{array}$ & $\begin{array}{l}\text { Participants had to present a panel (within SL, using } \\
\text { their avatars) on global and local leaders (in which } \\
\text { case they had to interview, film and present local } \\
\text { leaders). }\end{array}$ \\
\hline 3rd Meeting & $\begin{array}{l}\text { Real consulting - } \\
\text { problem diagnosis }\end{array}$ & $\begin{array}{l}\text { Meeting in SL, for leadership advice, with a real IT } \\
\text { company. A representative of the company, with its } \\
\text { avatar, presented the problem to be solved (in groups) } \\
\text { by the students. }\end{array}$ \\
\hline 4th Meeting & $\begin{array}{l}\text { Consulting - } \\
\text { prognosis } \\
\text { delivered by } \\
\text { groups to company } \\
\text { managers }\end{array}$ & $\begin{array}{l}\text { Meeting in SL, with the presentation of the consulting } \\
\text { solutions defined by each group to the direction of the } \\
\text { real IT company. }\end{array}$ \\
\hline Closing & $\begin{array}{l}\text { Closing lunch } \\
\text { meeting }\end{array}$ & $\begin{array}{l}\text { This meeting including the research team, students, } \\
\text { teachers and the managers of the IT company that was } \\
\text { consulted, all of whom evaluated the training. }\end{array}$ \\
\hline $\begin{array}{l}\text { Application } \\
\text { of } \\
\text { instruments } \\
\text { (self- } \\
\text { reported) }\end{array}$ & $\begin{array}{l}\text { Final diagnostic } \\
\text { self-assessment }\end{array}$ & $\begin{array}{l}\text { Again, the students individually responded to the } \\
\text { quantitative-qualitative instrument of their leadership } \\
\text { competency (by self-assessment). They also answered } \\
\text { a questionnaire to evaluate the training. }\end{array}$ \\
\hline
\end{tabular}

Note. Source: Research Data 
In addition, a self-assessment tool to be applied to students at the beginning and end of the training was developed. This instrument aimed to verify the participants' perceptions about fundamental aspects of leadership and to enable self-evaluation of their perception regarding their level of development of this personal competence.

It should be noted that this self-assessment instrument was an integral part of the artefact. It was created based on the theoretical leadership framework presented and was validated with three $\mathrm{Ph} . \mathrm{D}$. professors known in the area of competence development and leadership.

The application of the leadership training method follow-up was conducted, with the application of the training method developed in two classes of the course with a total of 12 students. At the development stage, data collection was diversified, including: a) participant observation (since the main researcher participated as the facilitator of all the activities developed in the metaverse (SL); b) field diary observations of this phase in general, discussions between the researcher and students; and c) photographing and filming of the activities carried out in the metaverse SL.

\subsection{Evaluation}

This fourth step of DSR included the follow-up and evaluation of the training process by the participants. Evaluation is a key step in every DSR project and different types of evaluation exist (e.g., observational, analytical, experimental, etc.) (Hevner et al., 2004). Evaluation features can be used in the form of software frameworks to evaluate artefacts in different stages, for example.

The evaluation of the training method in SL, which was the artefact itself, initially occurred in the form of observation and adjustments by the researcher in discussion with the research team, which occurred throughout the application of the training and not only at the end.

The concern was to evaluate the virtual space created within the SL island by the university and the set of educational activities proposed by the training. The evaluation of the development of leadership attributes was undertaken with the students throughout the whole process. It was conducted in a formative way, such as through observation and feedback after each activity; students were asked to reflect on the lessons learned after each activity and to send their insights via e-mail to the principal investigator, who acted as the facilitator of the training. 
This strategy, in addition to allowing more individualized follow-up, also provided opportunities to make adjustments during the training process. Accordingly, evaluation took place throughout the development process and in the end, this evaluation was complemented in reports that summarized the development of activities and documents to share the knowledge generated, which will be detailed in the next phase.

\subsection{Conclusion}

Finally, after the end of the training, a meeting and final lunch were held with the participation of all involved in the study. The purpose of this meeting was to perform an analysis of the work as a whole. As a result, the post-qualification self-assessment was conducted and feedback exchanged among researchers, facilitators and students, including members of the company in which the consulting took place.

The goal of this step was to consolidate the data collected throughout the research and to bring the artefact considerations into account. This enables the research to be better understood and replicated, while the anomalies that could not be explained represent suggestions for subjects of further research (Manson, 2006).

Accordingly, this step resulted in the development of a master's thesis and academic articles, in addition to DSR method development workshops. For the analysis of the results and development of the dissertation and articles, the researchers sought the reduction and structuring of the qualitative data, which according to Collis and Hussey (2005) involves data categorization. In this research, categorization was based on the theoretical reference adopted, considering mainly the verification of leadership attribute development and the contributions of the use of the artefact. NVIVO® software was used for the analysis.

\section{Research Contributions}

The research contributions were generated from the creation and use of the created artefact. Because of the iterative nature of DSR processes (e.g., Hevner et al., 2004; Peffers et al., 2007), researchers will, in most cases, work with various versions of their artefact and its functional Decomposition. The term artefact was used to describe something that is artificial, or constructed by humans, in contrast to something that occurs naturally (Simon, 1996). In the present research, the final artefact was composed of the following outputs: 
- Quantitative and qualitative diagnostic tool for leadership competence (by self-assessment) - applied at the beginning of training and at the end of training.

- Training of students to use the metaverse SL.

- Capacity building for the development of the leadership competency proper in SL, which consisted of a series of practical activities for the development of this competence.

- Tools for the evaluation of the training by the participants.

\subsection{Artefact use contributions}

This discussion is based on the educational affordances of the metaverses (Dalgarno, 2010). Table 4 highlights the pieces of evidence of the affordances of metaverse SL perceived during the application of the artefact (empowerment method for leadership development). Based on the results and the theoretical synthesis, the evidence also points out the difficulties encountered during the application of the artefact. 
Table No. 4: Synthesis of evidence of the educational affordances of the metaverse

\begin{tabular}{|c|c|}
\hline Affordances & Evidence of affordance during artefact application \\
\hline Communication & $\begin{array}{l}\text { In all the meetings were used: } \\
\text { - voice; chat; gestures; } \\
\text { - Slide show } \\
\text { - Video (in the second meeting with São Leopoldo group); } \\
\text { - Use of Notecards (SL notepad) by students } \\
\text { - Sites placed in the environment, for access from within the SL. }\end{array}$ \\
\hline Interaction & $\begin{array}{l}\text { It was evidenced in all meetings by: } \\
\text { - Interactions between students; } \\
\text { - Interactions between the students and the facilitator; } \\
\text { - Interaction among the students, facilitator and guests of the } \\
\text { company. }\end{array}$ \\
\hline Collaboration & $\begin{array}{l}\text { - Discussion and sharing of information in all meetings; } \\
\text { - Dynamics of the } 1 \text { st meeting; } \\
\text { - Proposals from the 4th meeting, collaborating with the company. }\end{array}$ \\
\hline Simulation & $\begin{array}{l}\text { - Business meeting with the executive at the } 3 \text { rd meeting; } \\
\text { - Presentation of the real case during the } 4 \text { th meeting, simulating a } \\
\text { consultancy; }\end{array}$ \\
\hline $\begin{array}{l}\text { Visualization and } \\
\text { Contextualization }\end{array}$ & $\begin{array}{l}\text { - Visualization of information by various media } \\
\text { - Visualization of the avatars themselves; } \\
\text { - The environment created for the activity, reproducing the context } \\
\text { of a teamwork room; }\end{array}$ \\
\hline Feeling of presence & $\begin{array}{l}\text { - By the students, during feedback at the end of the training; } \\
\text { - By the facilitator, regarding the presence of students and also of } \\
\text { the support team, as recorded in the researcher's field diary. }\end{array}$ \\
\hline $\begin{array}{l}\text { Community } \\
\text { Presence }\end{array}$ & $\begin{array}{l}\text { - 2nd and 4th Meetings with the opportunity to collaborate with the } \\
\text { company; } \\
\text { - Mutual help in the dynamics of the 1st meeting }\end{array}$ \\
\hline Content production & $\begin{array}{l}\text { - 3rd meeting with the work of the global leader and local leader; } \\
\text { - Videos produced by students; } \\
\text { - Slides produced by students; }\end{array}$ \\
\hline
\end{tabular}

Note. Source: Research Data

The table above highlights the metaverse affordances evidence indicated in the literature, such as interaction and communication. These two are fundamental for the others to occur, for example, collaboration, as well as the identification of difficulties in relation to them, constitute an important diagnostic to seek improvements in collaboration, for example.

In addition, according to Salmon (2009), interaction is one of the most important affordances for education, because in virtual worlds, students and teachers need to focus on how they 
could work together in these virtual environments. Therefore, feeling of presence should be highlighted as an interaction component.

It was also verified that it is possible to share electronic files, objects and virtual constructions under the regime of the intense collaboration of the content generated by and for the users (Vrellis, Avouris, \& Mikropoulos, 2016), which favors the affordances of interaction, communication, and collaboration. Lu (2010) complements this idea by arguing that the metaverse allows multi-user collaboration to communicate ideas simultaneously.

However, it is worth noting that collaboration did not occur only within the metaverse. It was necessary (for both the facilitator and the students) to use other means external to the metaverse, such as WhatsApp, e-mail, other messaging applications, and face- and produce content, etc.

Difficulties in using SL tools to share information or writing, such as notecard, make this limitation very clear and what it implies, namely the need for other parallel means of collaboration.

Thus, the collaborative production tools provided by SL were not perceived as being easy to use. The affordances of visualization and contextualization were well characterized in the last encounter with the simulation of the consulting that provided the contextualization of the real case of the company. With this, the students were able to simulate a consultancy work and it was possible to problematize the content that worked, among other aspects, with the creativity of the students and their own ability to organize and lead the joint work.

In this experience, leadership skills such as interpersonal relationship capability, resilience to change, and planning capability and systemic vision were visibly mobilized in the students during the experiment. Concerning simulation affordance, it is an event built and intended to provide realistic approximations of experiences that are very difficult, expensive or dangerous to perform in a real environment (Bronack, 2011). In the activity carried out in this research (consulting), which was beyond the simulation, because it was real, it was realized that, although it is not an activity difficult to perform in the real environment, it provided a realistic approach for the students, who could discuss their solutions with a company director and the executive who presented the problem, all of whom were located in different physical environments (cities). 
With this, it can be inferred that if this activity were performed in person, it would involve costs, guests' displacement and time, which can be spared with the accomplishment of the activity in the metaverse.

It is worth mentioning that among the affordances already mentioned, one of the most perceived by the students was the sensation of social presence provided through the avatars virtual interaction, which could be verified by the students' feedback and by the researcher's field record. This falls within the definition of Bronack (2011), which states that presence has been defined as the feeling of being there, when "there" is a mediated space, as a virtual world.

One difficulty faced is related to the affordance of community presence, because due to the time constraint the researcher had to create strategies to students perceive this presence of each other. Thus, the affordance of community presence was less evidenced compared to other affordances.

Finally, it is worth highlighting a result that emerges in the feedbacks of the students, the motivational aspect of the training and the use of the metaverse for the academic activity, with special emphasis on the students for the last meeting. It was pointed out that the fact of dealing with the environment was challenging, innovative and, together with the development of real activity (consultancy), stimulated the students. This result is corroborated by the literature, which points out that the affordances of the environment provide differentiated support, with different interactions of the traditional classroom (Brown et al., 2008).

In summary, it is believed that with the development and application of the artefact developed, one can identify the perception of several affordances of metaverses for education indicated in the literature, but also their limitations, according to the context in which the research was carried out, and the lessons learned may be useful for future uses of metaverses such as SL. 


\subsection{Contributions in the development of leadership competence}

We noticed the research results are in line with the theoretical framework studied, since we aimed to give opportunities to experience situations in which students could exercise their leadership, in a collaborative way, together with the workgroup, to carry out contextualized activities, since competence is only manifested in the practical activity (notion of event), and it is from this activity that the evaluation of the competences used in it can proceed (Zafirian, 2001). The event notion also highlights the context-dependent characteristic of developing competencies. In other words, each scenario is unique and represents an important reference to developing competencies.

In addition, Le Boterf (2006) argues that competency is the set of social and communication learning fed, on the one hand, by learning and training and, on the other, by the evaluation system. Thus, competencies emerge from a specific context in which a set of social and technical combination elements is important to stimulate competencies development.

In this sense, an existing limitation is that the accomplishment of collaborative activities and the challenges proposed in the virtual environment have their limits, not to involve real risks as in the daily life of a company, and not to mobilize the same resources, among other aspects of an activity real. But the fact of simulating, or effectively, realizing and problematizing issues related to leadership within the metaverse can give the individual the possibility of self-awareness and be prepared for future challenges, once "behavior in a situation is never effectively prescriptive" (Zarifian, 2001, p. 71).

Besides, it was possible to underscore other competence's attributes that had not been highlighted in the literature considered important for leadership development and should be considered as a result of the training. They are: proactivity, commitment, courage and focus on results. Regarding these attributes, when reviewing the results of the research in the data collected in the stage of understanding the problem, it was possible to verify that the attributes of courage and proactivity were cited by the teachers interviewed, synthesizing the set of knowledge, abilities, and attitudes that show competence leadership. Table 5 bellow bring leadership evidence. 
Table No. 5: Evidence of leadership competence

\begin{tabular}{|c|c|}
\hline Comp & Evidences \\
\hline $\begin{array}{l}\text { Relationship } \\
\text { (internally and } \\
\text { externally) }\end{array}$ & $\begin{array}{l}\text { - It was one of the most worked attributes; } \\
\text { - It was possible to observe him in the interactions in all the meetings; } \\
\text { - Communication } \\
\text { o Through interactions; } \\
\text { o For the discussions; } \\
\text { o Feedbacks; } \\
\text { o With the use of the system tools (Chat, voice command, gestures, } \\
\text { among others) }\end{array}$ \\
\hline $\begin{array}{l}\text { Resilience to } \\
\text { change }\end{array}$ & $\begin{array}{l}\text { - The use of the environment itself; } \\
\text { - Attitude towards proposed challenges; } \\
\text { - Courage evidenced through the attitude of the students in the } \\
\text { proposed challenges; } \\
\text { - Proactivity: } \\
\text { o By the observed attitude of the students; } \\
\text { o By the video made by the students; } \\
\text { o By the observed initiatives. }\end{array}$ \\
\hline $\begin{array}{l}\text { Plar } \\
\text { Sys } \\
\text { (str: }\end{array}$ & $\begin{array}{l}\text { - By the observation of the researcher in the planning of the activities } \\
\text { elaborated by the students; } \\
\text { - By the discussions and reflections during and after the activities; }\end{array}$ \\
\hline Decision Ability & $\begin{array}{l}\text { - The case of consulting for the company provided the work of this } \\
\text { attribute; } \\
\text { - Activity Global Leader and Local Leader provided the discussion and } \\
\text { decisions about the leader and presentation strategy. }\end{array}$ \\
\hline $\begin{array}{l}\text { Capability to } \\
\text { Stimulate (for } \\
\text { the leader to be } \\
\text { motivated) }\end{array}$ & $\begin{array}{l}\text { - Focus on the result, in presenting the results to the manager of the } \\
\text { invited company; } \\
\text { - Motivation (individual perspective) through feedback from students } \\
\text { and by the reports in the discussions; } \\
\text { - It was also discussed through reflections and conversations during } \\
\text { the last meeting; }\end{array}$ \\
\hline
\end{tabular}

Note. Source: Research Data

\subsection{Practical research contributions}

This study brings contribution regarding DSR method and also the metaverse training method presented in this research. Thus, future researchers or educators can replicate it or even develop something similar, the following observations stand out.

First of all, the researchers should keep in mind the DSR method allows you to make adjustments throughout the research development. So, it is possible to make some adjustments. It was verified that despite all the care in the knowledge of the problem and in 
the phase of the suggestions it is possible that problems, difficulties or some restrictions imposed by the artefact may occur.

Initially, we had some systems problems (difficulty with sound), difficulty in using Second Life features, such as notecards, the university wireless network infrastructure and the need for additional materials in computer labs, such as microphones. To overcome these problems, we had to use particular materials from the users and a computer lab instead of the Wi-Fi network.

Another finding is that the researcher has flexibility and remains motivated in the search for solutions or alternatives in the face of new demands that may occur. In addition, the researcher must be able to access institutional support/support people to expedite troubleshooting. Because, as stated in Figure 1 if the development phase comes up with some surprise we should go back one or two steps.

Regarding the artefact, we noticed the Second Life needs to improve the forms of interaction, sometimes hangs and when we need to make adjustments we use other means such as e-mail, WhatsApp, Skype, etc. The SL does not support all collaborative works. So, we contracted one game designer to produce some online features and the researchers produced some collaboratively composed outside the environment (e.g., videos, slides, etc.). Still related to second life use, it is necessary to a reserved online space; since SL is free, (avatars from other places can attend the training environment).

Concerning to development step we discussed, and we were careful to create activities that included all competences detailed in the theoretical revision. But there was initial difficulty in thinking of attractive activities that would mobilize students. After the consulting activity, which really challenged the students they started to interact more and get more motivated.

Besides, we verified difficulty of students to create avatars, the difficulty of students navigating the avatar, difficulty of the facilitator in dealing with technical problems and having to deal with the conduct of the activity, need for technical staff to create the environment. For this, it is necessary that the facilitator has a deep knowledge of the program, constant training, not only remote but face-to-face meetings, in the hands-on model.

It is important to mention that is necessary the availability of time of the facilitator or one instructor to create and apply the training. The same way, it is necessary to think in the 
availability of time for students to carry out their activities, as an alternative, we can use asynchronous activities, as challenges, since it does not need to gather all participants at the same time.

We comprehend that facilitator should be able not only to create the activities but also to manage all activities. Therefore, to replicate the training it is necessary to choose a person with some specific competences such as knowledge and familiarity with technology, ability to manage groups and teams, creativity, good communication skills, didactics, and motivation.

During the final steps of the DSR, it is necessary to keep focused, since the all process demand of time and dedication of the researcher to accompany activities. The evaluation and conclusion should be well detailed.

For step four, the evaluation, the researcher should be exempt and think of other looks of the activity. In the case, the self-evaluation of all the participants was sought, besides the analysis of the records of all meetings.

Finally, in the last step, the conclusion, we should be sought various ways to share the knowledge generated. For instance, we produced academic papers, reports, master dissertation, workshop, classes, among others.

\section{CONCLUSION}

This paper discussed the DSR applied in the development of leadership in undergraduate business administration students. For this, initially, the Design Science Research method was approached was detailed highlighting the steps according to the authors Hevner et al. (2004), Vaishnavi \& Kuechler (2004) and Manson (2006), which comprises 5 steps: understanding or awareness of the problem; suggestions; development; evaluation and conclusions.

The researchers presented the research steps, at the end it was possible to verified that metaverses contributes to the development of leadership competency by enabling the simulation of real work situations, considering experiences that would not be possible to be lived in other contexts neither face to face nor virtually, and by enabling a virtual environment with rich resources for interaction between leaders and their followers. As a main result and contribution of the research, it was possible to identify how the metaverse can 
be used as an environment for the development of leadership competence. Based on the lens of competencies, the use of DSR stimulates leadership development by (1) rescuing the importance of event (Zarifian, 2001) - competency development is a context-dependent process; (2) combining social and technological skills that emerge from the proposed activities in the SL. In other words, we highlight the emergence of competencies (Le Boterf, 2006) that is stimulated by the group activities (collectively) and also by feedbacks and in a self-development moment (individually).

As a methodological contribution, we highlight the use of DSR, which is still little used in research in Administration, and this is another potential contribution of this article.

Another result that is worth mentioning was that several leadership competences could be worked on within the metaverse SL, with emphasis on planning and systemic vision, decision making, relationship, communication, and resilience.

However, it should be emphasized that there is no pretension to affirm that students fully developed such competences and attributes proposed by each activity. But yes, that they were processed in a procedural way and the students were able to reflect and train themselves, taking another step in their leadership development process. Thus, the DSR stimulates the students to a self-development consciousness process that could inspire them to develop leadership competencies in future opportunities. It is not one moment lesson but an experience to last.

As the main contributions, in a practical way, it is believed that from the results of the research, several professionals could benefit as present in section four which brings practical contributions. It was found that students and educators have the possibility of using one more technology (metaverse) to cooperate with the study and with the development of leadership skills.

As suggestions for future research, we can highlight the use of the training method created in other contexts, or between other institutions, providing interaction and exchange of experiences among students, as well as with leaders in a corporate environment, in which this type of training is feasible. 
Finally, we suggest that conducting a lateral assessment between participants to complement the facilitator's assessment and self-assessment, to gain a more complete insight into the process of developing leadership competency.

As limitations of the research, we can highlight that, because it is a method in which the researcher proposes to develop an artefact, the complexity of Design Research is high, since it involves a large number of activities, especially during the understanding phase of problem and suggestion. Finally, the involvement of researchers in the application of the artefact is a limit, since the connection with the participants and with the experience itself can generate risks of a degree of bias, which should be a constant concern.

\section{REFERENCES}

1. Andreas, K., Tsiatsos, T., Terzidou, T., \& Pomportsis, A. (2010). Fostering collaborative learning in Second Life: Metaphors and affordances. Computers \& Education, 55(2), 603-615.

2. Baskerville, R.L., and J. Pries-Heje (2010) "Explanatory Design Theory", Business \& Information Systems Engineering, (2)5, pp. 271-282.

3. Baskerville, R., Baiyere, A., Gregor, S., Hevner, A., \& Rossi, M. (2018). Design science research contributions: finding a balance between artifact and theory. Journal of the Association for Information Systems, 19(5), 358-376.

4. Bennis, W., \& Levy, M. (1996). A formação do líder. São Paulo. Atlas.

5. Bennis, W. G., Nanus, B., \& Simõés, A. B. (1988). Líderes: estratégias para assumir a verdadeira liderança. Editorial Harbra.

6. Botha, S., \& Claassens, M. (2010). Leadership competencies: The contribution of the bachelor in management and leadership (BML) to the development of leaders at first national bank, South Africa. International Business \& Economics Research Journal, 9(10), 77-87.

7. Bronack, S. C. (2011). The role of immersive media in online education. The Journal of Continuing Higher Education, 59(2), 113-117.

8. Brown, E., Hobbs, M., \& Gordon, M. (2008). A virtual world environment for group work. International Journal of Web-Based Learning and Teaching Technologies (IJWLTT), 3(1), 1-12.

9. Cascio, W. F., \& Boudreau, J. W. (2016). The search for global competence: From international HR to talent management. Journal of World Business, 51(1), 103-114.

10. Coda, R., \& Bergamini, C. W. (1997). Psicodinâmica da vida organizacional: motivação e liderança. São Paulo: Atlas, 2.

11. Collis, J., \& Hussey, R. (2005). Pesquisa em administração: um guia prático para alunos de graduação e pós-graduação. Bookman.

12. Dalgarno, B., \& Lee, M. J. (2010). What are the learning affordances of 3-D virtual environments?. British Journal of Educational Technology, 41(1), 10-32.

13. Freitas Junior, J. C. S., Machado, L., Klein, A. Z., \& Freitas, A. S. (2015). Design Research: aplicações práticas e lições aprendidas. Revista de Administração FACES Journal, 14(1).

14. Gaver, W. W. (1991, April). Technology affordances. In Proceedings of the SIGCHI conference on Human factors in computing systems (pp. 79-84). ACM.

15. Gregor, S., Müller, O., \& Seidel, S. (2013). Reflection, abstraction, and theorizing in design and development research. In Proceedings of the 21st European Conference on Information Systems.

16. Gregor, S., \& Hevner, A. (2013). Positioning and presenting design science research for maximum impact. MIS Quarterly, 37(2), 337-355. 


\section{www.ijsrm.humanjournals.com}

17. Girvan, C., \& Savage, T. (2010). Identifying an appropriate pedagogy for virtual worlds: A Communal Constructivism case study. Computers \& Education, 55(1), 342-349.

18. Hevner, A. R., March, S. T., Park, J., \& Ram, S. (2004). Design science in information systems research. MIS Quarterly, 28(1), 75-105.

19. Hitt, M. A., Ireland, R. D., \& Hoskisson, R. E. (2012). Strategic management cases: competitiveness and globalization. Cengage Learning.

20. Hitt, M. A., Miller, C. C., \& Colella, A. (2007). Comportamento organizacional: uma abordagem estratégica. LTC.

21. Kuechler, W. L., \& Vaishnavi, V. (2012). A framework for theory development in design science research: Multiple perspectives. Journal of the Association for Information Systems, 13(6), 395-423.

22. Lacerda, D. P., Dresch, A., Proença, A., \& Antunes Júnior, J. A. V. (2013). Design Science Research: método de pesquisa para a engenharia de produção. Gestão \& produção, 20(4), 741-761.

23. Le Boterf, G. Avaliar a competência de um profissional: três dimensões a explorar [Internet].[local desconhecido]:[editora desconhecida]; 2006 [cited 2012 Mar 01] Available from: http://www. guyleboterfconseil. com. Article\% 20evalua tion\% 20version\% 20directe\% 20Pessoal. pdf.

24. Lu, L. (2010). Demystifying three-dimensional virtual worlds for art education. International Journal of Education through Art, 6(3), 279-292.

25. Manson, N. J. (2006). Is operations research really research?. Operations Research Society of South Africa, 22(2), 155-180.

26. Mettler, T., Eurich, M., \& Winter, R. (2014). On the Use of Experiments in Design Science Research: A Proposition of an Evaluation Framework. Communications of the Association for Information Systems, 34, pppp.

27. Peffers, K., Tuunanen, T., Rothenberger, M. A., \& Chatterjee, S. (2007). A design science research methodology for information systems research. Journal of management information systems, 24(3), 45-77.

28. Porter, M. E., \& Kramer, M. R. (2009). Estratégia e sociedade: o vínculo entre vantagem competitiva e responsabilidade social das empresas. PORTER, ME Competição. Rio de Janeiro: Elsevier, 483-507.

29. Rochlin, S. (2005). Responsabilidade empresarial no DNA da empresa. Harvard Business. 83(8), 19-25.

30. Rowe, W. G. (2002). Liderança estratégica e criação de valor. Revista de Administração de Empresas, 42(1), 1-15.

31. Saccol, A., Schlemmer, E., Barbosa, J., \& Hahn, R. (2011). M-learning e u-learning: novas perspectivas da aprendizagem móvel e ubíqua. São Paulo: Perarson, 30.

32. Salmon, G. (2009). The future for (second) life and learning. British Journal of Educational Technology, 40(3), 526-538.

33. Simon, H. A. (1996). The sciences of the artificial. MIT press.

34. Smart, J., Cascio, J., \& Paffendorf, J. (2007). Metaverse roadmap overview. Accelerated Studies Foundation.

35. Sommerville, I. (2016). Software engineering (10th ed.). New York, NY: Pearson.

36. Vaishnavi, V., and Kuechler, B.( 2004) Design research in information systems. Association for Information Systems. (available at www.isworld.org/Researchdesign/drisISworld.htm).

37. Vrellis, I., Avouris, N., \& Mikropoulos, T. A. (2016). Learning outcome, presence and satisfaction from a science activity in Second Life. Australasian Journal of Educational Technology, 32(1).

38. Vries, M. F. K., Marcondes, R. C., \& Marcondes, A. C. (1997). Liderança na empresa: como o comportamento dos líderes afeta a cultura interna. Atlas.

39. Warburton, S. (2009). Second Life in higher education: Assessing the potential for and the barriers to deploying virtual worlds in learning and teaching. British journal of educational technology, 40(3), 414-426.

40. Zarifian, P. (2001). Objetivo competência: por uma nova lógica. In Objetivo competência: por uma nova lógica. São Paulo: Atlas, 2001. 